\title{
Hubungan Kadar Albumin Serum dengan Neutrophil Gelatinase-Associated Lipocalin Urine pada Penderita Sindrom Nefrotik Anak
}

\author{
Deasy Nurisya, ${ }^{1}$ Heda Melinda Nataprawira, ${ }^{2}$ Nanan Sekarwana ${ }^{2}$ \\ ${ }^{1}$ Rumah Sakit Ibu dan Anak UMMI Bogor, ${ }^{2}$ Departemen Ilmu Kesehatan Anak Fakultas Kedokteran \\ Universitas Padjadjaran/Rumah Sakit Dr. Hasan Sadikin Bandung
}

\begin{abstract}
Abstrak
Neutrophil gelatinase-associated lipocalin (NGAL) merupakan penanda biologis kerusakan ginjal yang kadarnya meningkat sejalan dengan terjadinya kerusakan pada tubulus proksimal. Tujuan penelitian untuk menganalisis hubungan kadar albumin serum dengan NGAL urine pada penderita SN anak dalam serangan. Subjek adalah penderita SN dalam serangan berusia 1-14 tahun. Penelitian observasional analitik dengan metode potong lintang dilaksanakan di Departemen Ilmu Kesehatan Anak Rumah Sakit Dr. Hasan Sadikin Bandung dan Rumah Sakit Umum Daerah Kota Bandung dari September 2011 sampai Maret 2012. Pemeriksaan kadar albumin serum dilakukan dengan metode bromcresol green dan NGAL urine dengan metode enzyme-linked immunosorbent assay (ELISA). Uji statistik dengan Korelasi Pearson untuk data dengan distribusi normal. Subjek terdiri atas 14 lakilaki dan 10 perempuan. Kadar albumin serum rerata dan NGAL urine rerata adalah 1,37 (SB 0,33) g/dL dan 2.719,37 (SB 3.781,82) ng/mL. Hasil analisis menunjukkan hubungan bermakna antara penurunan kadar albumin serum dan peningkatan kadar NGAL urine $(\mathrm{r}=-0,519 ; \mathrm{p}=0,009)$. Simpulan, semakin rendah kadar albumin serum maka semakin tinggi kadar NGAL urine. Pada penderita SN anak dengan hipoalbuminemia perlu diwaspadai penurunan fungsi ginjal. [MKB. 2014;46(3):130-3]
\end{abstract}

Kata kunci: Albumin, anak, NGAL urine, sindrom nefrotik

\section{Correlation between Serum Albumin and Urine Neutrophil Gelatinase Associated Lipocalin Levels in Children with Nephrotic Syndrome}

\begin{abstract}
Neutrophil gelatinase-associated lipocalin (NGAL) is a biological marker found in kidney damage that increases in proximal tubular damage. The purpose of this study was to analyze the correlation between serum albumin and urine NGAL (uNGAL) levels in children with NS at initial presentation or relapse. Subjects in this study were 1-14 year-old children with NS. An observational analytical study with cross sectional design was conducted in the Pediatric Department of Dr. Hasan Sadikin General Hospital Bandung and Bandung City Public Hospital from September 2011 to March 2012. The serum albumin level and uNGAL level were measured using bromcresol green method and enzyme-linked immunosorbent assay (ELISA), respectively. Data were analyzed using Pearson correlation test on normal distribution data. Subjects consisted of 14 boys and 10 girls. Mean serum albumin and uNGAL levels were 1.37 (SD 0.33) g/dL and 2,719.37 (SD 3,781.82) ng/mL, respectively. There was a significant correlation between decreased albumin level and elevated uNGAL level $(\mathrm{r}=-0.519, \mathrm{p}=0.009)$. In conclusion, the lower the albumin level, the higher the UNGAL level. An awareness should be developed towards the possibility that hypoalbuminemia in children with NS might decrease renal function. [MKB. 2014;46(3):130-3]
\end{abstract}

Key words: Albumin, children, nephrotic syndrome, uNGAL

Korespondensi: Deasy Nurisya, dr., Sp.A, Rumah Sakit Ibu dan Anak (RSIA) UMMI Bogor, Jl. Empang II No.2, Bogor, mobile 08122117594,e-mail: deasynurisya@yahoo.com 


\section{Pendahuluan}

Pada sindrom nefrotik (SN) ditandai perubahan permeabilitas dinding kapiler glomerulus ginjal, sehingga akan terjadi kebocoran protein dalam urine yang mengakibatkan proteinuria masif serta hipoalbuminemia. ${ }^{1}$ Proteinuria yang terjadi menyebabkan kerusakan brush border tubulus proksimal. ${ }^{2}$ Peningkatan filtrasi dan reabsorbsi albumin oleh tubulus akan menimbulkan respons inflamasi interstisial. Edema interstisial yang terbentuk akan dapat menyebabkan obstruksi dan iskemia pada tubulus ginjal., ${ }^{3,4}$ Hipoalbuminemia menyebabkan hipovolemia dan penurunan renal blood flow (RBF) yang akan menurunkan laju filtrasi glomerulus (LFG). ${ }^{5}$ Renal blood flow dan LFG yang menurun menyebabkan iskemia pada tubulus proksimal. ${ }^{6}$

Pada sindrom nefrotik (SN), kadar neutrophil gelatinase-associated lipocalin (NGAL) urine meningkat oleh karena kehilangan pasif yang disebabkan kerusakan glomerulus dan tubulus proksimal, serta produksi aktif dari sel-sel tubulus yang iskemik. ${ }^{2}$ Kerusakan brush border pada tubulus proksimal menyebabkan berkurangnya reseptor untuk NGAL sehingga NGAL terdeteksi di dalam urine. ${ }^{2}$ Sel-sel tubulus proksimal yang iskemia secara aktif memproduksi NGAL.,7 Penelitian ini bertujuan untuk menilai hubungan antara kadar albumin dan NGAL urine pada penderita SN anak.

\section{Metode}

Penelitian observasional analitik dengan metode potong lintang dilaksanakan dari September 2011 sampai dengan Maret 2012. Subjek adalah penderita SN berusia 1-14 tahun di Rumah Sakit Dr. Hasan Sadikin (RSHS) Bandung dan Rumah Sakit Umum Daerah Kota Bandung. Penelitian ini telah mendapat persetujuan Komite Etik Penelitian Kesehatan Rumah Sakit Dr. Hasan Sadikin/Fakultas Kedokteran Unpad Bandung.

Kriteria inklusi adalah SN dalam serangan: serangan pertama atau kambuh jarang atau kambuh sering usia 1-14 tahun dan SN resisten steroid usia 1-14 tahun. Kriteria eksklusi pada penderita yang didiagnosis gagal ginjal kronik, sepsis, pembedahan jantung, sindrom hemolitik uremik (HUS), infeksi saluran kemih, dan juga keganasan (kanker ovarium, kolon, paru-paru, hepar).

Pemeriksaan kadar albumin serum dengan metode bromcresol green, menggunakan mesin Cobas 4000 dan NGAL urine dengan metode enzyme-linked immunosorbent assay (ELISA), mempergunakan mesin Stat Fax. Pemeriksaan albumin serum menggunakan bahan pemeriksaan berupa darah $3 \mathrm{cc}$ dan NGAL urine dengan bahan pemeriksaan berupa urine $3 \mathrm{cc}$, dilaksanakan di Departemen Patologi Klinik RSHS Bandung. Uji statistik dilakukan menggunakan statistical product and service solutions (SPSS) 17.0, pengolahan data dengan Korelasi Pearson untuk menilai arah hubungan dan kekuatan hubungan albumin serum dengan NGAL urine. Jumlah sampel ini ditentukan berdasarkan rumus besar sampel untuk analisis korelasi sebanyak minimal 22 subjek. Kemaknaan secara statistik ditentukan berdasarkan nilai $\mathrm{p}<0,05$.

\section{Hasil}

Selama periode September 2011-Maret 2012

Tabel 1 Karakteristik Subjek Penelitian $(n=24)$

\begin{tabular}{|c|c|c|}
\hline Karakteristik Subjek & & $\mathbf{n}$ \\
\hline \multicolumn{3}{|l|}{ Usia (bulan) } \\
\hline Rerata (SB) & $75(45,2)$ & \\
\hline Median & 65 & \\
\hline Rentang & $22-146$ & \\
\hline \multicolumn{3}{|l|}{ Jenis kelamin } \\
\hline Laki-laki & & 14 \\
\hline Perempuan & & 10 \\
\hline \multicolumn{3}{|l|}{ Diagnosis } \\
\hline Sindrom nefrotik relaps infrekuen & & 5 \\
\hline Sindrom nefrotik resisten steroid & & 6 \\
\hline Sindrom nefrotik serangan pertama & & 13 \\
\hline
\end{tabular}

Keterangan: n: jumlah sampel, SB: simpang baku 
Deasy Nurisya: Hubungan Kadar Albumin Serum dengan Neutrophil Gelatinase-Associated Lipocalin Urine

Tabel 2 Kadar Albumin Serum dan NGAL Urine Rerata Subjek Penelitian

\begin{tabular}{lccc}
\hline \multicolumn{1}{c}{ Variabel } & Rerata $(\mathbf{S B})$ & Median & Rentang \\
\hline Albumin serum $(\mathrm{g} / \mathrm{dL})$ & $1,37(0,33)$ & 1,35 & $0,80-2,20$ \\
NGAL urine $(\mathrm{ng} / \mathrm{mL})$ & $2.719,37(3.781,82)$ & 676,00 & $19-9.820$ \\
\hline
\end{tabular}

Keterangan: SB: simpang baku

didapat 24 penderita SN anak yang memenuhi kriteria inklusi, sebagian besar laki-laki, dan diagnosis terbanyak SN dalam serangan (Tabel 1). Hasil pemeriksaan subjek penelitian didapatkan kadar albumin serum rerata adalah $1,37 \mathrm{~g} / \mathrm{dL}$, kadar NGAL urine rerata adalah $2.719,37 \mathrm{ng} / \mathrm{mL}$ (Tabel 2). Hasil uji statistik dengan menggunakan Uji Korelasi Pearson pada tingkat kemaknaan $5 \%$ memperlihatkan hubungan bermakna antara kadar albumin serum dan NGAL urine penderita SN anak $(p=0,009)$ serta kekuatan hubungan negatif sedang $(\mathrm{r}=-0,519)$.

\section{Pembahasan}

Pada penelitian ini jenis kelamin yang terbanyak adalah laki-laki dengan rasio laki-laki berbanding perempuan 1,4:1. Hasil ini sesuai dengan yang dikemukakan oleh Niaudet ${ }^{8}$ serta Dolan dan Gill ${ }^{9}$ bahwa pada SN anak, laki-laki lebih banyak daripada perempuan.

Kadar NGAL urine rerata meningkat dari rerata normal dan terdapat rentang yang lebar. Nilai normal pada penelitian ini merujuk pada nilai yang tercantum pada kit reagen Human Lipocalin-2/NGAL, dengan rerata $9,94 \mathrm{ng} / \mathrm{mL}$ $(0,42-72 \mathrm{ng} / \mathrm{mL})$. Peningkatan kadar NGAL urine rerata pada subjek penelitian ini menunjukkan telah terjadi penurunan fungsi ginjal, perbedaan kadar pada setiap subjek dengan rentang yang cukup jauh menunjukkan kemungkinan berbagai derajat penurunan LFG dan kerusakan pada selsel tubulus. Neutrophil gelatinase-associated lipocalin merupakan penanda biologis untuk gangguan ginjal akut. Waktu pasti saat terjadinya proses yang akut sampai dengan saat dilakukan pengambilan sampel tidak diketahui, terjadinya tingkat kerusakan pada sel tubulus tidak diketahui dengan pasti, tidak dapat dilihat berdasarkan gejala klinis, sehingga didapatkan hasil NGAL dengan rentang yang lebar.

Hasil uji statistik dengan mempergunakan Uji Korelasi Pearson menunjukkan hubungan negatif dengan kriteria sedang dan bermakna antara penurunan kadar albumin serum dan peningkatan kadar NGAL urine.

Peningkatan NGAL dalam urine pada kondisi proteinuria melalui dua kemungkinan, pertama oleh karena kehilangan pasif yang disebabkan kerusakan glomerulus dan tubulus, kedua karena produksi aktif dari sel-sel tubulus yang rusak. Pada SN, terjadi peningkatan NGAL di tubulus melalui kerusakan membran kapiler glomerulus dan sistem kompleks megalin cubilin akan mengalami saturasi dengan cepat karena overload protein tubular. Kerusakan brush border tubulus proksimal menyebabkan kerusakan reseptor megalin, sehingga NGAL tidak dapat direabsorpsi. Kompleks megalin cubilin pada brush border ini juga akan bereaksi dengan protein lainnya sehingga jumlah yang dapat berikatan dengan NGAL akan berkurang. ${ }^{10}$ Pada penderita SN, albumin pada tubulus proksimal memiliki efek pada fungsi tubulointerstisial ketika difiltrasi secara berlebih pada tubulus proksimal. Secara in vivo, proteinuria berhubungan dengan proliferasi dan apoptosis dari proximal tubule cell (PTC) dan inflamasi interstitial. ${ }^{11}$ Pada penderita SN, peningkatan filtrasi dan reabsorpsi albumin oleh tubulus dapat menyebabkan respons inflamasi interstisial. Edema interstisial yang terbentuk akan menyebabkan obstruksi tubulus dan iskemia pada tubulus ginjal. ${ }^{3,4}$ Hipoalbuminemia menyebabkan hipovolemia yang menurunkan RBF dan LFG, penurunan RBF dan LFG menyebabkan selsel tubulus proksimal menjadi iskemik, ${ }^{6}$ yang secara aktif memproduksi NGAL.,10 Iskemia pada sel-sel tubulus dan obstruksi pada lumen tubulus menyebabkan peningkatan kadar NGAL urine, peningkatan ini telah terjadi saat iskemia tubulus yaitu saat fase inisiasi dari acute kidney injury. ${ }^{12}$

Penelitian pada anak dengan SN sensitif dan resisten steroid didapatkan hubungan negatif yang bermakna pada estimasi LFG dan NGAL urine, menunjukkan NGAL meningkat sejalan dengan penurunan fungsi ginjal pada SN. Kadar NGAL yang lebih tinggi pada SN resisten steroid menunjukkan bahwa NGAL berhubungan dengan beratnya penyakit. ${ }^{13}$ Pada penderita $\mathrm{SN}$ dengan makroproteinuria, kadar NGAL urine meningkat dibandingkan dengan subjek sehat. ${ }^{7}$ Pada laporan kasus SN dewasa dengan edema yaitu saat terjadi proteinuria masif dan hipoalbuminemia, kadar NGAL lebih tinggi dibandingkan dengan saat terjadi perbaikan klinis. ${ }^{2}$ Keterbatasan penelitian ini yaitu diagnosis SN yang tidak homogen.

Simpulan, terdapathubungan negatifbermakna dengan kekuatan sedang antara penurunan kadar 
albumin dan peningkatan kadar NGAL urine pada penderita SN. Dengan diketahuinya kekuatan dan bentuk hubungan tersebut, maka pada anak penderita SN hipoalbuminemia perlu diwaspadai terdapat penurunan fungsi ginjal.

\section{Daftar Pustaka}

1. Bagga A, Mantan M. Nephrotic syndrome in children. Indian J Med Res. 2005;122(1):1328.

2. Kuwabara T, Mori K, Mukoyama M, Kasahara M, Yokoi H, Saito Y, dkk, Urineary neutrophil gelatinase-associated lipocalin levels reflect damage to glomeruli, proximal tubules, and distal nephrons. Kidney Int. 2009; 75(3):285-94.

3. Agarwal N, Phadke KD, Garg I, Alexander $P$. Acute renal failure in children with idiopathic nephrotic syndrome. Pediatr Nephrol. 2003;18(12):1289-92.

4. Koomans HA. Pathophysiology of acute renal failure in idiopatic nephrotic syndrome. Nephrol Dial Transplant. 2001;16(2):221-4.

5. de Seigneux S, Martin PY. Management of patients with nephrotic syndrome. Swiss Med Wkly. 2009;139(29-30):416-22.

6. Sutton TA, Fisher CJ, Molitoris BA. Microvascular endothelial injury and dysfunction durineg ischemic acute renal failure. Kidney Int. 2002;62(5):1539-49.

7. Bolignano D, Coppolino G, Lacquaniti A, Nicocia G, Buemi M. Pathological and prognostic value of urineary neutrophil gelatinase-associated lipocalin in macroproteinuric patients with worsening renal function. Kidney Blood Press Res. 2008;31(4):274-9.

8. Niaudet P. Steroid-sensitive idiopathic nephrotic syndrome in children. Dalam: Avner ED, Harmon WE, Niaudet P, penyunting. Pediatric nephrology. Edisi ke-5. Philadelphia: Lippincott Williams \& Wilkins; 2004. hlm. 518-35.

9. Dolan NM, Gill D. Management of nephrotic syndrome. Paediatr and Child Health. 2008;18(8):369-74.

10. Bolignano D, Donato V, Coppolino G, Campo S, Buemi A, Lacquaniti A, dkk. Neutrophil gelatinase-associated lipocalin (NGAL) as a marker of kidney damage. Am J Kidney Dis. 2008;52(3):595-605.

11. Arici M, Chana R, Lewington A, Brown J, Brunskill NJ. Stimulation of proximal tubular cell apoptosis by albumin-bound fatty acids mediated by peroxisome proliferator activated receptor- $\gamma$. J Am Soc Nephrol. 2003;14(1): 17-27.

12. Vaidya VS, Ferguson MA, Bonventre JV. Biomarkers of acute kidney injury. Annu Rev Pharmacol Toxicol. 2008;48:463-93.

13. Bennett MR, Piyaphanee N, Czech K, Mitsnefes M, Devarajan P. NGAL distinguishes steroid sensitivity in idiopathic nephrotic syndrome. Pediatr Nephrol. 2012;27(5):807-12. 